\title{
Murottal and Clasical Music Therapy Reducing Pra Cardiac Chateterization Anxiety
}

\section{Sapta Darmadi ${ }^{1}$, Yunie Armiyati ${ }^{2}$}

${ }^{1}$ Dr. Kariadi General Hospital Semarang

2 University of Muhamadiyah Semarang

\section{Article Info}

\section{Article History:}

Accepted September 30th 2019

\section{Key words:}

Classical music; Murottal therapy; Anxiety; Cardiac catheterization

\section{INTRODUCTION}

The World Health Organization (WHO) reports that an estimated 17.9 million people died from Cardiovascular diseases (CVDs) in 2016, representing $31 \%$ of all global deaths. Of these deaths, $85 \%$ are due to heart attack and stroke. ${ }^{1}$ Indonesia has a tendency to increase the incidence of cardiovascular disease. The national

\begin{abstract}
The high incidence of patients with coronary heart disease is directly proportional to the increase in cardiac catheterization. Many patients who experience anxiety pre heart catheterization will need nursing action. Relaxation with classical music therapy and or murottal therapy can reduce patient anxiety. The aim of this study was to determine the effectiveness of murottal therapy and classical music therapy to reduce the anxiety of patients pre heart catheterization in the Elang Installation of Dr. Kariadi Hospital Semarang. The study was a Quasi Experiment study with two group pre and post test design. The research sample consisted of 16 patients in the classical music therapy group and 16 in the murottal therapy group. The results of the study showed that there were differences in the effectiveness of murottal therapy and classical music therapy to decrease the anxiety of patients pre heart catheterization in the Elang Installation of Dr. Kariadi Hospital Semarang (p-value 0.028). Murottal therapy is more effective in reducing anxiety. Music therapy and murottal therapy given with a duration of 30 minutes creates a calm and comfortable atmosphere so that the body becomes more relaxed, blood circulation more smoothly, blood pressure and other vital signs will decrease and can reduce anxiety in patients pre cardiac catheterization. Murottal therapy is more effective in reducing anxiety. It is hoped that the results of this study will become the basis of hospital agencies in developing Standard Operating Procedure (SPO) management of anxiety in the provision of nursing care to patients cardiac pre-catheterization.
\end{abstract}

Corresponding author:

Yunie Armiyati yunie@unimus.ac.id

prevalence for heart disease in 2018 is 1,5\% based on diagnosis by health professionals and symptoms. ${ }^{2}$

Cardiovascular disease is a public health problem in developed and developing countries, this disease is divided into 3 groups, namely heart function disorders, heart structure disorders, infections and non-inflammation, and disorders of the 
vascular system. ${ }^{3}$ Based on the proportion of urban mortality in the 45-54 years age group, ischemic heart disease ranks third $(8.7 \%)$ as the cause of death, first place is stroke $(15.9 \%)$ and second place is diabetes mellitus (14.7\%). The prevalence of coronary heart disease based on diagnosed doctor interviews in Indonesia increases with age by $0.5 \%$, and based on diagnosed doctors or symptoms by $1.5 \% .^{2}$ According to the Survey Sample Regristration System (SRS) at 2014 in Indonesia, it showed that coronary heart disease (CHD) was the highest cause of death in all ages after stroke by $12.9 \%{ }^{4}$

Various methods are used to recognize the diagnosis of coronary heart disease, ranging from non-invasive techniques such as electrocardiography (ECG) to invasive examinations such as coronary angiography (cardiac catheterization). Catheterization (derived from the word cardiac catheterization, or heart catheterization and abbreviated as catheterization) is the act of inserting a small tube (catheter) into the arteries and / or veins and tracing them to the heart, other blood vessels and / or other organs to which they are directed Xray assistance. ${ }^{5}$ Cardiac catheterization has therapeutic and diagnostic support functions but also has risks in the form of arrhythmias, emboli, nerve changes, vasovagal changes and other additional disorders that are ischemic, allergic and vascular complications.

A total of 2631 patients undergoing cardiac catheterization at RSUP Dr. Kariadi Semarang, among them 1,920 (73\%) had coronary intervention (cardiac catheterization by stenting). Numerous studies shown that the action of cardiac catheterization can cause anxiety in patients, efforts to reduce anxiety can be given with nonpharmacological therapy.

Cardiac catheterization is an invasive procedure that for some people will have a psychological impact on the patient. Patients who will undergo invasive cardiac catheterization procedures will experience feelings of anxiety and stress. The magnitude of the impact caused by anxiety will affect the activity of the central nervous system to activate the hypothalamus pituitary adrenal axis and the sympathetic nervous system which is characterized by an increase in pulse frequency and blood pressure. This is very dangerous because the high heart rate and blood pressure will aggravate the cardiovascular system and increase oxygen demand and heart work. ${ }^{6}$ Patient's anxiety needs to get special attention in nursing because every nursing action must quickly make effective coping of the patient in order to reduce perceived stress so that physiological and emotional balance is achieved. ${ }^{7}$

Preliminary study data at Dr. Kariadi Hospital Semarang in August 2018 showed that most patients who will undergo cardiac catheterization experience anxiety. It is not uncommon to delay catheterization because the patient's anxiety affects hemodynamics. Survey of 10 patients who will undergo cardiac catheterization found that $100 \%$ of patients expressed anxiety, 50\% experienced moderate anxiety, 10\% experienced severe anxiety and 40 people experienced mild anxiety. The results of interviews with the person in charge of the cardiac catheterization room, nurses and doctors in the cardiac catheterization room of Dr. Kariadi Hospital found that most of the patient's response when he entered the heart catheterization room, facial expressions looked scared, confused, some even had a sudden increase in blood pressure and increased heart rate.

Nurses must implement appropriate interventions to deal with patient anxiety. Various non-pharmacological measures of independent management based on Nursing Intervention Classification (NIC) can be done to overcome patient anxiety including relaxation therapy, guided imagination, increased safety, music therapy, counseling and meditation facilitation. ${ }^{8}$ 
Listening to music has a moderate effect on anxiety in people with coranary heart desease (CHD). Studies that used music interventions in people with myocardial infarction found more consistent anxietyreducing effects of music. ${ }^{9}$ Music stimulation increases endorphine release and this decreases the need for drugs. The release of endorphins also provides a distraction from pain and can reduce anxiety. ${ }^{10}$ Religious therapy with murottal Al Qur'an verses can also speed healing. Study in $s$ to determine the effect of murrotal audio therapy of Qur'an Surah ArRahman to the level of anxiety in presurgery senile cataract patients showed there was the influence of anxiety differences of respondents before and after given audio therapy Qur'an Surah ArRahman. ${ }^{11}$ Research has shown the effect of murottal (Al-Qur'an) therapy on reducing anxiety levels of patients who will undergo laparatomy surgery. ${ }^{12}$

The use of murotal music therapy and classical music both can significantly reduce the anxiety of patients with various cases of the disease, including in patients who will undergo surgery. It is necessary to examine which interventions are better and more effective in reducing the anxiety of patients undergoing cardiac catheterization. Researchers interested in examining the effectiveness of murottal therapy and classical music therapy on reducing anxiety of patients pre cardiac catheterization at the Elang Installation of Dr. Kariadi General Hospital Semarang.

\section{METHODS}

The research method used was quasy experimental (quasy experiment) with the research design is two group pre and post test design. The target population in this study were all patients who will undergo cardiac catheterization at the Elang Installation of Dr. Kariadi General Hospital Semarang with the sampling technique in this study using purposive random sampling. The research sample calculated using the Federer formula obtained a sample of 16 people as a group who were given classical music therapy and 16 people as a group who were given murottal therapy selected according to the inclusion criteria, namely patients treated in the Eagle Room of RSUP Dr. Kariadi Semarang, the first Iscemic Heart Disease (IHD) patient who will undergo a cardiac catheterization program, more than 30 years old and cooperative, muslim, patients with mild to severe anxiety, male sex, minimum education at primary school.

The study was conducted in February - May 2019 in the Elang Installation of Dr. Kariadi General Hospital Semarang by paying attention to research ethics including the principle of benefits, the principle of respecting human rights (respect human dignity) and the principle of justice (right to justice). An ethical clearancec letter issued by the Medical Research Ethics Commission Diponegoro University.

Data collection instruments in this study were carried out using an anxiety measurement tool which in its use of the interview method. Anxiety level measurement tool is the Numeric Rating Scale (NRS) for anxiety. Anxiety score is assessed based on the range of intensity of anxiety felt by the client with a zero score category said there is no anxiety, a value of 10-30 mild anxiety, a value of 40-60 moderate anxiety, a value of $70-90$ severe anxiety, and a value of 100 panic. The instrument of classical was performed using a Mozart Clarinet Concerto In A Major K 622 Adagio classical music by using smart phone. Murottal therapy surah Ar-Rahman sung by Muzammil Hasballah with a medium timbre, $44 \mathrm{~Hz}$ pitch, regular harmony and consitent, rhythm andate lilting, volume 60 decibels, medium intensity amplitude with a time duration of 30 minutes. The intervention was carried out by giving classical music and murottal surah Ar Rahman to each group, listening by lying down for 30 minutes using headphones. Anxiety scale is measured 
before and after the intervention in each group.

Data were analyzed by univariate and bivariate tests. Analysis of differences in anxiety levels in patients pre cardiac catheterization before and after given murottal therapy and classical music therapy using the Wilcoxon test. Analysis of the differences in murottal therapy and classical music therapy on the reduction in anxiety of patients pre cardiac catheterization at the Elang Installation of Dr. Kariadi Semarang Hospital uses the Mann-Whitney Test.

\section{RESULTS}

The results showed the average age of respondents in group I (classical music therapy) is 44.25 years and the oldest age is 56 years. Group II (murottal therapy) obtained an average age of respondents was 45.38 years and the oldest age was 56 years.

The results showed that patients who will undergo cardiac catheterization more in the respondents with undergraduate education by $62.5 \%$ in group I and $43.8 \%$ in group II. Occupational respondents the majority work as private employees as many as 6 people (37.5\%) group I (classical music therapy) and 5 people (31.2\%) in group II (murottal therapy). Length of stay was 1 day for 8 people (50\%) in group I and 9 people $(56.2 \%)$ in group II.
Table 1

Distribusi Responden Berdasarkan Pekerjaan, Pendidikan dan Lama Hari Rawat

\begin{tabular}{lcccc}
\hline \multirow{2}{*}{ Characteristik } & \multicolumn{2}{c}{$\begin{array}{c}\text { Group I } \\
\text { Clasical Music } \\
\text { Therapy) }\end{array}$} & \multicolumn{2}{c}{$\begin{array}{c}\text { Group II } \\
\text { (Murottal } \\
\text { Therapy) }\end{array}$} \\
\cline { 2 - 5 } Job & $\mathrm{f}$ & $\%$ & $\mathrm{f}$ & $\%$ \\
Not working & 2 & 12,5 & 2 & 12,5 \\
Private & 2 & 12,5 & 1 & 6,2 \\
employees & 6 & 37,5 & 5 & 31,2 \\
Laborers & 4 & 25,0 & 5 & 31,2 \\
Entrepreneur & 2 & 12,5 & 3 & 18,8 \\
Civil servants & & & & \\
Education & & & & \\
Junior High & 1 & 6,2 & 2 & 12,5 \\
School & 10 & 62,5 & 7 & 43,8 \\
Senior High & 5 & 31,2 & 7 & 43,8 \\
School & & & & \\
College & & & & \\
Length of stay & & & & \\
1 day & 8 & 50,0 & 9 & 56,2 \\
2 days & 5 & 31,2 & 5 & 31,2 \\
3 days & 3 & 18,8 & 2 & 12,5 \\
\hline Total & 16 & 100 & 16 & 100 \\
\hline
\end{tabular}

The results showed that before being given classical music therapy the majority of respondents experienced moderate anxiety, namely as many as 10 people (62.5\%). After being given classical music therapy there was a decrease in the level of anxiety in respondents, the majority (56.2\%) experienced mild anxiety.

Table 2

Anxiety Level Before and After Being Given Classical Music Therapy $(n=16)$

\begin{tabular}{lcccc}
\hline $\begin{array}{c}\text { Anxiety level group I } \\
\text { (Classical Music } \\
\text { Therapy) }\end{array}$ & \multicolumn{2}{c}{$\begin{array}{c}\text { Before } \\
\text { Classical } \\
\text { Music } \\
\text { Therapy }\end{array}$} & \multicolumn{2}{c}{$\begin{array}{c}\text { After } \\
\text { Classical } \\
\text { Music } \\
\text { Therapy }\end{array}$} \\
\cline { 2 - 5 } & $\mathrm{f}$ & $\%$ & $\mathrm{f}$ & $\%$ \\
\hline Mild anxiety & 4 & 25,0 & 9 & 56,2 \\
Medium anxiety & 10 & 62,5 & 7 & 43,8 \\
Severe anxiety & 2 & 12,5 & 0 & 0,0 \\
\hline Total & 16 & 100 & 16 & 100 \\
\hline
\end{tabular}

The anxiety level of respondents after being given murottal therapy decreased with an average decrease in anxiety level score 20.62 compared to before being given murottal therapy and the majority after 
being given murottal therapy experienced mild anxiety by 13 people $(81.2 \%)$ compared to before being given music therapy, the majority (75.0\%) experienced moderate anxiety.

Table 3

Anxiety Level Before and After Being Given Murottal Therapy $(n=16)$

\begin{tabular}{lcccc}
\hline $\begin{array}{c}\text { Anxiety level } \\
\text { group II (Murottal } \\
\text { Therapy) }\end{array}$ & \multicolumn{2}{c}{$\begin{array}{c}\text { Before } \\
\text { Murottal } \\
\text { Therapy }\end{array}$} & \multicolumn{2}{c}{$\begin{array}{c}\text { After } \\
\text { Murottal } \\
\text { Therapy }\end{array}$} \\
\cline { 2 - 5 } & $\mathrm{f}$ & $\%$ & $\mathrm{f}$ & $\%$ \\
\hline Mild anxiety & 2 & 12,5 & 13 & 81,2 \\
Medium anxiety & 12 & 75,0 & 3 & 18,8 \\
Severe anxiety & 2 & 12,5 & 0 & 0,0 \\
\hline Total & 16 & 100 & 16 & 100 \\
\hline
\end{tabular}

The results of statistical analysis with Wilcoxon test showed that in group I (classical music therapy) decreased anxiety levels of 12 people (75.0\%) and increased and remained as many as 2 people each (12.5\%). Group II (murottal therapy) showed that as many as 15 people $(93.75 \%)$ had decreased anxiety levels and only 1 person $(6.25 \%)$ with a fixed anxiety level.

Table 4

Differences in Anxiety Levels Before and After Being Given Classical Music Therapy and Murottal

\begin{tabular}{|c|c|c|c|c|}
\hline Variabel & Respons & $\mathrm{f}$ & $\begin{array}{l}\text { Mean } \\
\text { Rank }\end{array}$ & $\begin{array}{c}\mathrm{p}- \\
\text { value }\end{array}$ \\
\hline \multirow{3}{*}{$\begin{array}{l}\text { Anxiety level } \\
\text { before and } \\
\text { after classical } \\
\text { music therapy }\end{array}$} & Increase & 12 & \multirow{6}{*}{8} & \multirow{6}{*}{$0,001^{*}$} \\
\hline & Decrease & 2 & & \\
\hline & Not change & 2 & & \\
\hline \multirow{3}{*}{$\begin{array}{l}\text { Anxiety level } \\
\text { before and } \\
\text { after murottal } \\
\text { therapy }\end{array}$} & Increase & 15 & & \\
\hline & Decrease & 0 & & \\
\hline & Not change & 1 & & \\
\hline
\end{tabular}

Wilcoxon test*

The results showed that the average decrease in anxiety levels in group II (murottal therapy) was higher at 19.97 compared to group I (classical music therapy) by 13.03. Research shows that there is a difference between murottal therapy and classical music therapy to decrease patient anxiety before cardiac catheterization at Elang Instalation of Dr. Kariadi Hospital Semarang.

Table 5

Differences in the Effectiveness of Murottal Therapy and Classical Music Therapy Against Decreased

Patient Anxiety Before Cardiac Catheterization (n1

\begin{tabular}{llc}
\multicolumn{2}{c}{$\mathrm{n} 2=16)$} & \\
\hline Decrease of anxiety level & $\begin{array}{l}\text { Mean } \\
\text { Rank }\end{array}$ & p- value \\
\hline $\begin{array}{l}\text { Group I (Clasical Music } \\
\text { Therapy) }\end{array}$ & 13,03 & \\
$\begin{array}{l}\text { Group II (Murottal } \\
\text { Therapy) }\end{array}$ & 19,97 & 0,028 \\
\hline
\end{tabular}

\section{DISCUSSION}

The results of this study indicate that the average patient who will undergo cardiac catheterization is an adult age. Cardiac catheterization patients tend to increase in adulthood. This is due to lack of awareness of running healthy habits. Coronary heart disease arises due to abnormal accumulation of lipids or levels of fat and fibrous tissue in the walls of blood vessels that result in changes in the structure and function of the arteries caused by ateroslerosis. Atherosclerosis causes inadequate blood supply to the heart and heart muscle cells to lack blood components. This causes ischemia in the heart muscles so that the patient will experience chest pain and in more severe ischemic conditions can be accompanied by damage to heart cells that are. ${ }^{3}$ The patient's age also influences the type of relaxation therapy that will be given. Adult patients tend to prefer relaxation therapy that is selfapproach to God, so that the provision of nursing interventions that are in accordance with the patient's age criteria will help in the success of the patient's health and care program.

The results showed that patients who will undergo cardiac catheterization more in the respondents with undergraduate education by $62.5 \%$ in group I and $43.8 \%$ in group II. One of the trigger factors that can cause 
anxiety is education status. The higher a person's education, the level of anxiety tends to decrease compared with people who have a low level of education. Low educational levels were significantly associated with both anxiety and depression. ${ }^{13}$ The level of anxiety is closely related to the level of education, where someone will be able to find information or receive information well. A high level of education will quickly understand the conditions and circumstances that will cause increased anxiety in the person.

The work of respondents in this study found that the majority worked as private employees as many as 6 people $(37.5 \%)$ group I (classical music therapy) and 5 people (31.2\%) in group II (murottal therapy). Work is one of the reasons for patients experiencing anxiety when a heart catheterization will be performed. This is due to the patient's concern for the safety of the soul and the patient's ability to perform work after the action. Patients who have jobs that require physical exertion will experience a decrease in the ability for patients to do so so that they appear worried about the threat of continuing their work and have an effect on the socioeconomy of the family. ${ }^{14}$

The results of this study showed that the majority of days of treatment were 1 day as many as 8 people (50\%) in the classical music group and 9 people (56.2\%) in the murottal therapy group. Length of stay related to the patient's experience of the heart catheterization to be performed. Previous experience of surgery and information obtained by the patient on the first day through the explanation of informed consent will affect the knowledge of the patient about the procedure for cardiac catheterization to be performed so that it will reduce anxiety and anxiety in patients. $^{7}$

After being given classical music therapy there was a decrease in the level of anxiety in respondents where the majority experienced mild anxiety by 9 people $(56.2 \%)$ with the lowest value of 20 and the highest of 50, and an average level of anxiety of 34.38. The results of research on the level of anxiety experienced by patients before undergoing cardiac catheterization increased with the approaching time of action, moreover cardiac catheterization has been known to have various kinds of possible complications during the process of action. Psychological preparation is needed by patients who will undergo cardiac catheterization.

The results of this study are in line with the results of several existing studies. Other research in patients with preoperative laparotomy shows that before being given murottal (Al-Qur'an) therapy, moderate anxiety was $56.2 \%$ and severe anxiety was $43.8 \%$. After being given murottal (AlQur'an) therapy, most $(65,6 \%)$ experienced mild anxiety. ${ }^{12}$ The systematic review indicates that music listening may have a beneficial effect on preoperative anxiety. These findings are consistent with the findings of three other Cochrane systematic reviews on the use of music interventions for anxiety reduction in medical patients. ${ }^{9}$

Anxiety is an obscure and pervasive concern, which is related to feelings of uncertainty and helplessness. This anxiety does not have a specific object, which is experienced subjectively and communicated interpersonal. ${ }^{15}$ One of independent nursing intervention to overcome anxiety is to provide classical music therapy and murottal therapy. Classical music and murottal therapy provides a relaxing and calming effect so that it can reduce anxiety in patients. The sound of clasiccal music and the Qur'an creates a group of frequencies that reach the ear and then moves to the brain cells and influences them through the electromagnetic fields this frequency is produced in these cells. The cells will respond to these fields and modify their vibrations. This change in vibration can make the brain relax and calm. 
The results showed a decrease in anxiety levels after given murottal therapy. Murrotal auditory stimulation has a relaxing effect increase the formation of endorphins in the control system descent and make relaxation. ${ }^{16}$ Listening to the verses of the Qur'an has a calming effect and makes the patient closer to His creator. Based on this, the patient can surrender and surrender all the conditions set by God for the heart catheterization that will be undertaken by the patient, so that the patient can become more relaxed and reduce anxiety on the patient.

Al-Qur'an reading murottal has a constant rhythm, regular and no sudden changes. Murottal al-Qur'an's tempo and low notes have a relaxing effect and can reduce stress and anxiety. ${ }^{17}$ Murottal therapy will increase one's awareness of God, whether that person knows the meaning of the Qur'an or not. This awareness will lead to totality surrender to Allah, in this state the brain in alpha waves in the form of brain waves creates optimal brain energy so that it can relieve stress and reduce anxietyn. ${ }^{18}$

The results of this study indicate a p-value of 0.007 in group I and 0.001 in group II $<\alpha$ (0.05), it can be concluded that there is a significant difference between anxiety levels in patients pre-cardiac catheterization before and after classical music therapy and murottal therapy at RSUP dr. Kariadi Semarang. Classical music therapy and murottal therapy are both sounds that can provide a therapeutic effect by providing relaxation to the patient so as to reduce the anxiety experienced by patients pre cardiac catheterization. Music therapy and murottal therapy given with a duration of 30 minutes creates a calm and comfortable atmosphere so that the body becomes more relaxed, blood circulation more smoothly, blood pressure and other vital signs will decrease and can reduce anxiety in patients pre cardiac catheterization. However, interventions with classical music therapy still found patients with increased anxiety levels after being given classical music therapy. This is because the music therapy given is less favored by the patient, so the patient's concentration cannot focus on the music given and still imagine the heart catheterization action to be performed.

Murottal therapy in this study can reduce the level of anxiety of patients pre cardiac catheterization. This is because essentially murottal Al-Qur'an therapy with regular rhythm and correct reading is also a music. The Qur'an is able to bring calm and minimize anxiety. Murottal therapy works on the brain, wherewhen driven by external stimulation (therapy Al-Quran) then the brain produces chemicals that are called neuropeptide. ${ }^{17}$ These molecules transport their existing receptors in the body so the body gives bait behind a sense of comfort.The administration of murottal AlQur'an therapy has been proven to be effective in increasing $\beta$-endorphine levels in patients who are sung with slow, gentle, full-of-depth tempers that can cause a relaxation response. Auditory (sound) therapy can reduce stress hormones, activate natural endorphins, increase feelings of relaxation, and divert attention from fear, anxiety and tension, improve the body's chemical system so that it lowers blood pressure and slows down breathing, heart rate, pulse, and brain wave activit. ${ }^{10}$

Murottal therapy can reduce anxiety scores by $42.8 \%$ while classical music therapy can reduce anxiety scores in preterm cardiac catheterization patients by $23.6 \%$. This study showed $93.75 \%$ of respondents experienced a decrease in anxiety scale and only 1 respondent $(6.25 \%)$ did not experience a change in anxiety scale. The decrease in anxiety occurs because the murottal therapy given is more understandable by the respondent. Murottal therapy in the form of chanting AlQur'an verses of the Ar-Rahman letter can be felt soothing to the heart, calming and getting closer to God so that patients are more relaxed and reduce the level of anxiety pre cardiac catheterization. 
The Qur'an has a great influence on a person's psyche. listening to the Qur'an will give you the effect of peace in the body because of the elements of meditation, autosuggestion and relaxation. This sense of calm will then provide a positive emotional response that is very influential in bringing about positive perception. ${ }^{18}$ Researchers used Ar-rahman's letter because of the surah contains a great wisdom for humanity in general and for Muslims in particular. This is related to the degree of thankfulness in the broadest sense of the meaning of the disobedience of the giver (Allah Almighty). Surah Arrahman is preceded by a statement about the nature of Allah, the Beneficent God. His generosity is the source of all the gifts given to all mankind.

Research showed using murottal therapy is more effective in reducing anxiety levels in patients pre cardiac catheterization compared to classical music therapy. This is possible because murottal therapy has an indispensable aspect in overcoming anxiety, namely its ability to form new coping to overcome anxiety before undergoing cardiac catheterization. Other studies also support the findings of this study. Research in postoperative patients shows that murottal therapy has been shown to be more effective in reducing anxiety compared to other music therapies urottal therapy has been proven to be more effective in reducing anxiety compared to other music therapies Murottal therapy has an indispensable aspect inovercoming anxiety, murottal has the ability to form a new coping to overcome anxiety. Murottal therapy has two important points, has a beautiful rhythm and also can psychologically motivate and provide encouragement in facing the problems being faced. ${ }^{10}$ Whereas in music therapy, it only has one point, which has a beautiful tone. Murottal also increases calm because there is a spiritual closeness to God.

We recommend that nurses can apply the provision of murottal Qur'an and classical music therapy to overcome the anxiety of patients who will undergo cardiac catheterization surgery. To reduce the anxiety of Muslim patients, nurses can apply murottal Al Qur'an.

\section{CONCLUSION}

Murottal therapy and classical music in reducing anxiety in patients pre cardiac catheterization. Nurses can apply classical music therapy and murotal therapy to reduce the anxiety of patients who will undergo cardiac catheterization.

\section{ACKNOWLEDGEMENTS}

We wish to express our appreciation to all patients who participated in this study and to the dr. Kariadi General Hospital Semarang for valuable assistance during data collection.

\section{CONFLICTS OF INTEREST}

Neither of the authors have any conflicts of interests that would bias the findings presented here.

\section{REFERENCES}

1. WHO. Cardiovascular diseases (CVDs)2013 [cited 201922 September]. Available from: https://www.who.int/news-room/factsheets/detail/cardiovascular-diseases-(cvds).

2. Balitbangkes. Hasil utama Riskesdas 2018 Jakarta: Kemenkes; 2018 [cited 201907 November ]. Available from: http://www.depkes.go.id/resources/downloa d/info-terkini/hasil-riskesdas-2018.pdf.

3. Smeltzer SC, Bare BG, Hinkle JL, Cheever KH. Brunner \& Suddarth's textbook of medicalsurgical nursing. 13th ed: Lippincott Williams \& Wilkins; 2013.

4. Kemenkes. Penyakit Jantung Penyebab Kematian Tertinggi, Kemenkes Ingatkan CERDIK2017 20 September 2019 [cited 2017 29 July]. Available from: http://www.depkes.go.id/article/view/17073 100005/penyakit-jantung-penyebabkematian-tertinggi-kemenkes-ingatkan-cerdik.html. 
5. PDSKI. Pedoman laboratorium kateterisasi jantung dan pembuluh darah. Jakarta: PDSKI; 2018.

6. Darliana D. Perawatan pasien yang menjalani prosedur kateterisasi jantung. Idea Nursing Journal. 2012;3(3).

7. Potter PA, Perry AG, Stockert PA, Hall AM. Fundamental of nursing. 9 ed. Pensylvania: Elsevier; 2017.

8. Butcher HK, Bulechek GM, Dochterman JMMC, Wagner C. Nursing Interventions Classification (NIC) - E-Book: Elsevier Health Sciences; 2018. Available from: https://books.google.co.id/books?id=L4lIDwA AQBAJ.

9. Bradt J, Dileo C, Potvin N. Music for stress and anxiety reduction in coronary heart disease patients. Cochrane Database of Systematic Reviews. 2013(12).

10. Faradisi F, Aktifah N. Pengaruh pemberian terapi Murottal terhadap penurunan kecemasan post operasi. Profesi (Profesional Islam): Media Publikasi Penelitian. 2018;15(2):6.

11. Syafei A, Suryadi Y. Pengaruh pemberian terapi audio Murottal Qur'an surat Ar-Rahman terhadap tingkat kecemasan pada pasien preoperasi Katarak Senilis. Jurnal Kesehatan. 2018;9(1):126-30.
12. Faridah VN. Terapi murottal (Al-Qur'an) mampu menurunkan tingkat Kecemasan pada pasien pre operasi laparatomi. Jurnal Keperawatan. 2016;6(1).

13. Bjelland I, Krokstad S, Mykletun A, Dahl AA, Tell GS, Tambs K. Does a higher educational level protect against anxiety and depression? The HUNT study. Social science \& medicine. 2008;66(6):1334-45.

14. Hawari D. Manajemen stress, cemas dan depresi. Jakarta: Fakultas Kedokteran Universitas Indonesia; 2014.

15. Stuart GW. Principle and practice of pscychiatric nursing. 10 ed. St Louis: Elsevier; 2013.

16. Armiyati $\mathrm{Y}$, editor Pengaruh perangsangan auditori Murrotal (ayat-ayat suci Al-Qur'an) terhadap nyeri pada pasien yang terpasang ventilator mekanik di ruang ICU Rumah Sakit Islam Sultan Agung Semarang. Konferensi nasional PPNI Jawa Tengah; 2017. Semarang.

17. Widyarti. Pengaruh bacaan Al-qur'an terhadap intensitas kecemasan pasien sindroma koroner akut di RS Hasan Sadikin Bandung: Padjajaran University; 2011.

18. Rahayu DA, Hidayati TN, Imam TA. The Effect of Murottal Therapy in Decreasing Depression of Patients Undergoing Hemodialysis. Media Keperawatan Indonesia. 2018;1(2):6-. 